\title{
Evaluation of the Levels of Some Heavy Metal Contents of Street Dust in Some Parts of Yola Metropolis, Adamawa State, Nigeria
}

Philip $\mathbf{M}^{1^{\star}}$, Louis $\mathrm{H}^{2^{\star}}$, Magu TO${ }^{2}$, Fidelis TT, Maitera $\mathrm{ON}^{1^{\star}}$ and Opara $\mathrm{I}^{1}$

${ }^{1}$ Department of Chemistry, Modibbo Adama University of Technology, PMB 2076 Yola, Adamawa State, Nigeria

${ }^{2}$ Department of Pure and Applied Chemistry, University of Calabar, PMB 115 Calabar, Cross River State, Nigeria

\begin{abstract}
Automobile emission and anthropogenic activities has been found to constitute a major sources of air pollution. This work investigated the level of some heavy metals $(\mathrm{Pb}, \mathrm{Cd}, \mathrm{Fe}$ and $\mathrm{Zn}$ ) in street dust of Bachure, Chemistry Department, Jaga-Jaga Market, Vonuklang and Shinko, Adamawa state, Nigeria. The results showed that the highest and lowest metal concentrations were found in the heavy traffic sites, anthropogenic activities and control sites respectively. The concentration of $\mathrm{Pb}$ was observed to increase from $1.24 \mu \mathrm{g} / \mathrm{m}^{3}$ in Bachure to $2.89 \mu \mathrm{g} / \mathrm{m}^{3}$ in Shinko. Cd was also observed to increase from $0.016 \mu \mathrm{g} / \mathrm{m}^{3}$ in Bachure to $0.066 \mu \mathrm{g} / \mathrm{m}^{3}$. Fe was observed to be between 18.60 in Bachure to as high as $34.80 \mu \mathrm{g} / \mathrm{m}^{3}$ in Shinko, while $\mathrm{Zn}$ was observed to be between 2.4 in Bachure to as high as $5.4 \mu \mathrm{g} / \mathrm{m}^{3}$ in Shinko. The concentration of all the heavy metals were observed to be higher than the permissible health limit for urban areas recommended by environmental protection agency (EPA).
\end{abstract}

Keywords: Heavy metal; Dust particle; Anthropogenic

\section{Introduction}

Heavy metal refers to metallic chemical element that has relatively high density which is usually toxic even at low concentrations. Human activities such as industrial production, mining, agriculture and transportation, release high amount of heavy metals into the surface and ground water, soils and ultimately to the biosphere [1,2]. Some of the heavy metals considered in this study include Cadmiun (Cd), Lead $(\mathrm{Pb})$, Iron $(\mathrm{Fe})$ and $\mathrm{Zinc}(\mathrm{Zn})$.

It was also known that mining, smelting and quarrying activities have created local environmental effects throughout the world and in the past have led to acute or chronic intoxication due to the emission of trace metals such as lead $(\mathrm{Pb})$, arsenic (As), cadmium $(\mathrm{Cd})$, and mercury $(\mathrm{Hg})[3]$.

Cd has been widely dispersed into the environment through the air by its mining and smelting as well as other by other man-made routes which include usage of fertilizers, presence of sewage and various industrial uses such as NiCd batteries, plating, pigment and plastics [4]. Cd may find its way into human population through food and beverages, drinking water, air, and cigarette smoking [5]. Cd fumes can damage the olfactory organs. Chronic exposure produces variety of effects on kidneys, lungs, heart, bones (asteomalaciia and Osteoporosis in humans and animals), and gonads. $\mathrm{Pb}$ is known for its toxic effect in the body. It's cumulative and long term exposure has been known to caused serious health hazard which include inhibition of the synthesis of haemoglobin and also adverse effects on kidney etc. Fe and $\mathrm{Zn}$ are also regarded as essential metals and has been found to be poisonous at high concentration.

Accumulation of heavy metals including $\mathrm{Pb}, \mathrm{Zn}$, and $\mathrm{Cu}$ on urban surfaces can be attributed to vehicle exhausts, industrial discharges, oil lubricants, automobiles parts, corrosion of building materials, atmospheric deposition [6]. Exhaust from all combustion engines combined to produce local adverse effects on the health of people especially automobile users and pedestrians. People leaving along highways, high traffic congested areas, production industries, automobile workshops are usually at high risk of heavy metals poisoning. The worst sufferers are traffic policemen, who are particularly close to the fumes of automobile exhaust [7].
Dust consist of solid matter particulates in the form of fine powder lying on the ground, on the surface of objects or blown about by natural or mechanical forces [8]. The presence of heavy metals in dust has been identified as useful indicators for contamination in surface soil, sediments and dust environments. Generally, the degree of concentration and accumulation of heavy metals in environmental indices depend on the type of heavy metals and the activities taking place in a particular area [9].

It is a fact that street dust is an important pathway in the exposure of people to toxic elements. The ingestion of dust particles with high concentration of potentially toxic metals, possess a potential threat to human health. For instance, in California, 5-10\% of allergen city for atmospheric total suspended particulate matter was attributed to paved road dust emissions [10]. Heavy metals are persistent pollutant that can be biomagnified in the food chain, becoming increasingly dangerous to humans and wild life. Therefore, assessing metal pollutants in different component of the ecosystem have become an important task in preventing risk to natural life and public health [11].

Exposure to metals in the air is capable of causing a myriad of human health effects, ranging from cardiovascular and pulmonary inflammation to cancer and damage of vital organs. Contemporary

*Corresponding authors: Philip M, Department of Chemistry, Modibbo Adama University of Technology, PMB 2076 Yola, Adamawa State, Nigeria, Tel: +23490287690043; E-mail: philipmonday1988@gmail.com

Louis H, Department of Pure and Applied Chemistry, University of Calabar PMB 115 Calabar, Cross River State, Nigeria, Tel: +2348077829220; E-mail: louis.hitler@unical.edu.ng

Maitera ON, Department of Chemistry, Modibbo Adama University of Technology, PMB 2076 Yola, Adamawa State, Nigeria, Tel: +2348027885324; E-mail: olivermaitera@yahoo.com

Received March 20, 2017; Accepted March 25, 2017; Published April 06, 2017

Citation: Philip M, Louis H, Magu TO, Fidelis TT, Maitera ON, et al. (2017) Evaluation of the Levels of Some Heavy Metal Contents of Street Dust in Some Parts of Yola Metropolis, Adamawa State, Nigeria. J Environ Anal Toxicol 7: 453. doi: 10.4172/2161-0525.1000453

Copyright: @ 2017 Philip M, et al. This is an open-access article distributed under the terms of the Creative Commons Attribution License, which permits unrestricted use, distribution, and reproduction in any medium, provided the original author and source are credited. 
Citation: Philip M, Louis H, Magu TO, Fidelis TT, Maitera ON, et al. (2017) Evaluation of the Levels of Some Heavy Metal Contents of Street Dust in Some Parts of Yola Metropolis, Adamawa State, Nigeria. J Environ Anal Toxicol 7: 453. doi: 10.4172/2161-0525.1000453

Page 2 of 4

research into air pollution is revealing that the metals components of particulate matter (PM) are contributing significantly to adverse health effects, even at the low concentrations found in ambient air. Metals such as $\mathrm{Cd}, \mathrm{Ni}$ and $\mathrm{Pb}$ are known examples of elements that exact pronounced negative health effects from inhalation and have been observed from both occupational and ambient air exposure. Environmental challenges posed by the proliferation of human activities such as industrial effluent discharge, vehicular emissions, bush burning, wastes incineration and have become evident in the industrial and high traffic density areas of yola metropolis but there is dearth of baseline data on the levels of heavy metal pollutants in dust over the areas. It was also observed that very little interest has been developed on metal contaminations of street dust despite its direct contact with greater part of every population [7]. Thus, this study sought to provide preliminary information on the levels of some heavy metals in street dust over the industrial and high traffic density areas of yola metropolis.

\section{Experimental Site and Location}

The study was conducted at Yola, Adamawa State, Nigeria. The study sites (Bachure, Shinko, Jaga-Jaga market, vonuklang and chemistry department) are located on latitude $9^{\circ} 01 \mathrm{~N}$ to $9^{\circ} 50 \mathrm{~N}$ and Longitude $12^{\circ} 15 \mathrm{E}$ to $12^{\circ} 40 \mathrm{E}$. With the exception of Bachure which serves as the control site because of its relatively low traffic density, the rest of the study sites are located along the Mubi Road and were selected for this study due to their high traffic density, industrial and agricultural activities as well as other peculiar activities described below.

\section{Description of location}

Shinko is characterized by the presence of small scale industrial activities such as blacksmithing and timberworks. Other activities include panel beating, battery charging, welding and fabrication, auto mechanic workshops, petrol stations and motor parks. There is a wide dumping site by the side of the Mubi road, proximal to the Benue River where agricultural activities like irrigation farming and fishing are taking place. There is also constant combustion of refuse including polymeric materials making visibility difficult especially for drivers, causing frequent cases of auto-crash while simultaneously polluting the community. $80 \%$ of the youths in shinko are Tobacco and Indian hemp smokers Shinko is linked to Vonuklang by the 1.2 kilometer Hayin-gada Bridge.

Vonuklang is characterized by similar activities as Shinko, with only the absence of road side dumping site, refuse combustion and timber works.

Jaga-jaga market is some $5 \mathrm{~km}$ away from Vunoklang. It is located at the base of the Bagale rock where commercial activities are taking place. This location possesses similar characteristics as Vonuglang with the absence of agricultural activities and timber works. This market is located just outside the main gate of Modibbo Adama University of Technology, Yola where chemistry department is located, some 1.5 Kilometers away from the university main gate which is close to JagaJaga market. Both Jaga-Jaga market and the university are situated close to the Bagale rock, which is sedimentary rock.

Bachure serves as the control site. Samples were collected along Bachure bus stop, also serves as a mini market where activities such as battery charging, barber shops, food and fruit sellers, generator workshop, kiosks and beer parlors (Figures 1-5).

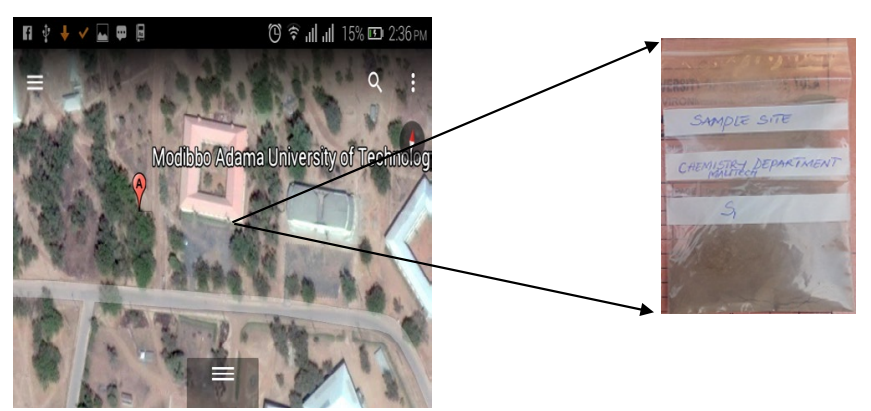

Figure 1: Map of Chemistry Department.

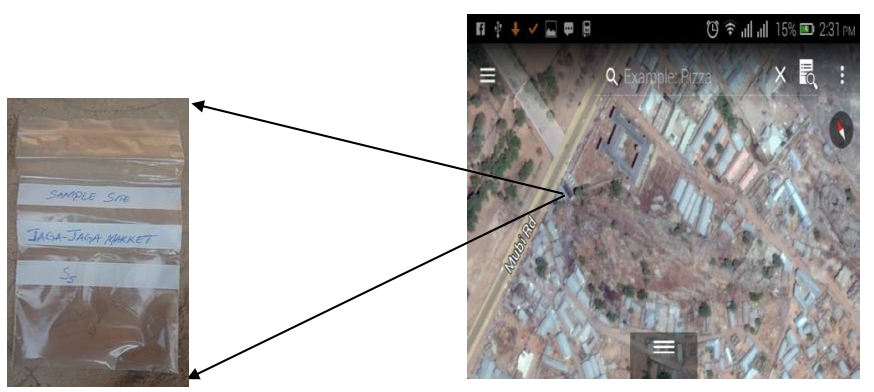

Figure 2: Jaga-Jaga Market Opposite MAUTECH Yola.

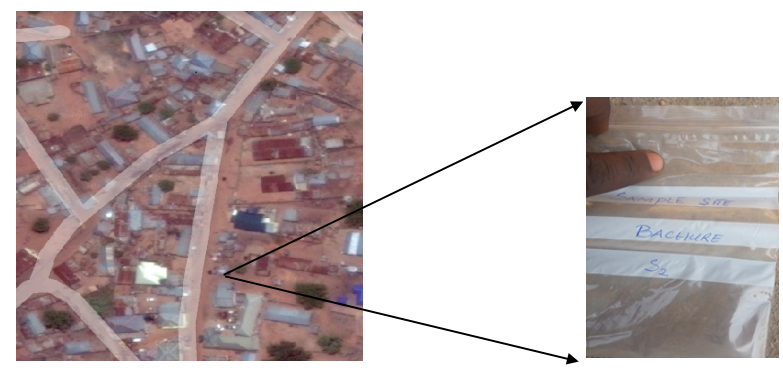

Figure 3: Bachure Settlement.

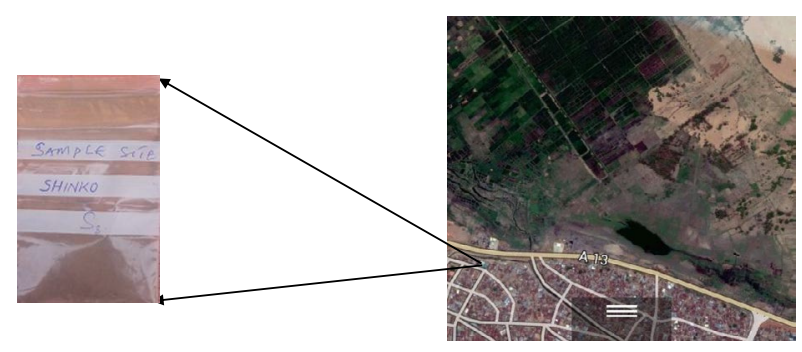

Figure 4: Shiko Settlement.

\section{Experimental}

\section{Sampling}

In total there are five sampling sites. At each sample site, five rectangular flat glasses of dimension $100 \mathrm{~cm}$ by $50 \mathrm{~cm}$ were placed at different points each 100 meters away from the road and from each other. The dust samples were collected by direct gravitational deposition on these glasses for the period of three weeks. The five glasses of each sample station were collected and mixed and then transferred into 
Citation: Philip M, Louis H, Magu TO, Fidelis TT, Maitera ON, et al. (2017) Evaluation of the Levels of Some Heavy Metal Contents of Street Dust in Some Parts of Yola Metropolis, Adamawa State, Nigeria. J Environ Anal Toxicol 7: 453. doi: 10.4172/2161-0525.1000453

Page 3 of 4

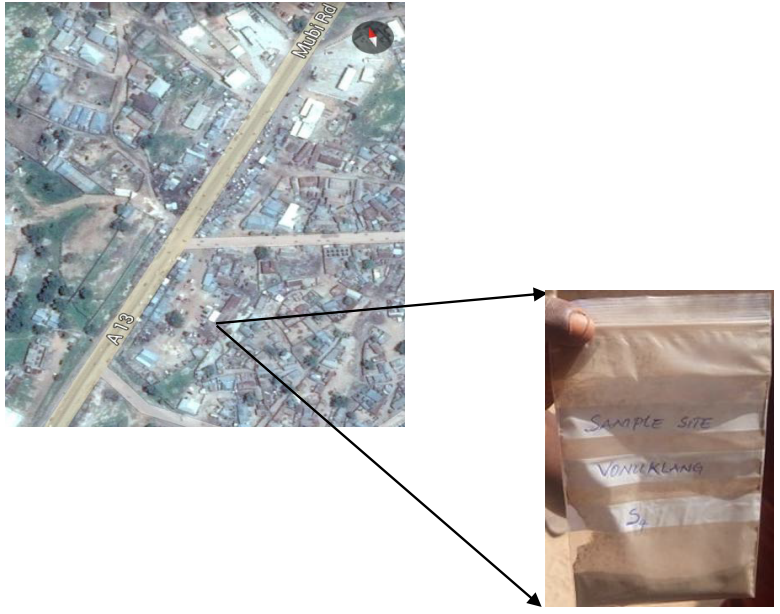

Figure 5: Vunoklang Settlement.

labeled clinical sampling packs and were taken to the laboratory for further preparation and analysis.

\section{Preparation of samples for analytical determinations}

The Bulk samples was oven dried at $105^{\circ} \mathrm{C}$ for 24 hours to drive out moisture and then passed through a $2 \mathrm{~mm}$ metal free sieve to remove unwanted fragments and pebbles. For analyzing heavy metals $(\mathrm{Pb}, \mathrm{Cd}$, $\mathrm{Zn}$ and $\mathrm{Fe}$ ), $1 \mathrm{~g}$ of each of the dried filtered sample was weighed using electronic balance and was transferred into $100 \mathrm{ml}$ volumetric flask and digested using $20 \mathrm{ml}$ nitric acid at $210^{\circ} \mathrm{C}$ during 90 minutes. The digest was cooled and $0.1 \mathrm{~N} \mathrm{HCl}$ was added to make it up to the $100 \mathrm{ml}$ mark on the volumetric flask. Each of the digested samples was subjected to the FAAS (flame atomic absorption spectrophotometer) machine for the determination of the absorbance of the heavy metals $(\mathrm{Pb}, \mathrm{Cd}$, $\mathrm{Zn}$ and $\mathrm{Fe}$ ). The graph for the absorbance against the serial dilution concentration in part per million was plotted, and the concentrations in $\mathrm{ppm}$ for $\mathrm{Pb}, \mathrm{Cd}, \mathrm{Zn}$ and $\mathrm{Fe}$ in the samples were obtained through extrapolation. The result was converted to microgram.

\section{Discussion}

\section{Lead}

As can be seen in Table 1 above the level of lead ranges between 1.24 in Bachure to as high as $2.89 \mu \mathrm{g} / \mathrm{m}^{3}$ in shinko, meaning all the sampling sites are polluted by lead since their concentrations happens to fall above EPA's standard health limits of $0.04 \mu \mathrm{g} / \mathrm{m}^{3}$ for Urban areas. The high level of lead may be attributed to lead smelting and automotive. Notice that despite being the site with the highest traffic density (as shown in Table 2), Vonuklang records lower concentration of lead than shinko, this could be as a result of the additional combustion of leaded polymeric wastes constantly taking place along the Mubi road in Shinko. Bachure which serves as control with the lowest traffic density nevertheless has its concentration above the EPA's standard. This could be the result of constant use of generators by the barber shops and phone battery chargers. It also could be attributed to absence of a tarred road, so that the lead concentration in the soil gets agitated by automobiles and wind into the air and settles in the dust, increasing its concentration. Also notice that lead level at chemistry department which happens to be farther away from the Mubi Road, is higher than the EPA's standard. There is every tendency that some of the particulate matter from Jaja-Jaga market may have been transported by wind to chemistry department accounting for its high concentration.

\section{Cadmium}

The level of Cd ranges from 0.019 in bachure to as high as 0.066 $\mu \mathrm{g} / \mathrm{m}^{3}$ in shinko. This high level of concentration may be as a result of automobile emission, constant open space burning of refuse, improper industrial waste disposal, Agricultural activities (like the spreading of pesticides, fertilizers application) smoking of tobacco and burning of fossil fuels, which are activities that characterize these locations.

\section{Zinc}

The level of $\mathrm{Zn}$ ranges between 2.4 in Bachure to as high as $5.4 \mu \mathrm{g} /$ $\mathrm{m}^{3}$ in Shinko as can be seen in Table 1 above. These concentrations are higher than the EPA'S standard limit of $0.103 \mu \mathrm{g} / \mathrm{M}^{3}$. The high level of zinc in these locations may have originated from traffic sources, such as wear, tear of vulcanized vehicle, tires, smelting and steel processing activities, the corrosion of metallic parts in scrap yards, lubricants and exhaust emissions from both gasoline and diesel fuelled road vehicles [12-14].

\section{Iron}

The iron level ranges from 18.60 in Bachure to as high as $34.80 \mu \mathrm{g} /$ $\mathrm{M}^{3}$ in Shinko. As can be seen in the table above, these concentraions have by far exceeded the EPA'S health limit of $1.6 \mu \mathrm{g} / \mathrm{M}^{3}$. The high iron contents of the particulate matter in these areas could be due to high incidence of wear off from car bodies, incineration of iron-rich wastes, as well as welding and blacksmithing that exist in the area. Another reason for the high level of irons in these locations may be connected to the fact that the rocks around these sites are igneous in nature. Igneous rocks contain iron deposits.

\section{Conclusion}

The results of this study revealed that the presence of heavy metals

\begin{tabular}{|c|c|c|c|c|c|c|}
\hline Element & Shinko & Vunoklang & $\begin{array}{c}\text { Jaga- } \\
\text { jaga } \\
\text { market }\end{array}$ & $\begin{array}{c}\text { Chemistry } \\
\text { Department }\end{array}$ & Bachure & $\begin{array}{c}\text { *EPA Health } \\
\text { limits for } \\
\text { Urban } \\
\text { areas }\end{array}$ \\
\hline $\mathrm{Pb}$ & 2.890 & 2.400 & 2.23 & 1.55 & 1.24 & 0.04 \\
\hline $\mathrm{Cd}$ & 0.066 & 0.039 & 0.039 & 0.031 & 0.019 & 0.008 \\
\hline $\mathrm{Zn}$ & 5.4 & 5.25 & 4.65 & 4.45 & 2.40 & 0.103 \\
\hline $\mathrm{Fe}$ & 34.80 & 32.44 & 31.64 & 29.60 & 18.60 & 1.6 \\
\hline
\end{tabular}

*Andrea Geiger and John Cooper

Table 1: Shows the various concentrations in $\mu \mathrm{g} / \mathrm{m}^{3}$ of $\mathrm{Fe}, \mathrm{Zn}, \mathrm{Pb}$ and $\mathrm{Cd}$ and the EPA Health limits for urban areas for each of the metals.

\begin{tabular}{|c|c|c|c|c|c|}
\hline $\begin{array}{c}\text { No. of vehicle per } \\
\text { hour }\end{array}$ & Shinko & Vonuklang & $\begin{array}{c}\text { Jaga- } \\
\text { jaga } \\
\text { market }\end{array}$ & $\begin{array}{c}\text { Chemistry } \\
\text { Department }\end{array}$ & Bachure \\
\hline $10-11$ am & 1505 & 1699 & 1444 & 105 & 150 \\
\hline $11-12$ noon & 1231 & 1500 & 1105 & 98 & 123 \\
\hline $12-1$ pm & 918 & 896 & 798 & 78 & 21 \\
\hline $1-2$ pm & 1150 & 1323 & 703 & 125 & 34 \\
\hline $\begin{array}{c}\text { Average No. of } \\
\text { vehicles per hour. }\end{array}$ & 1201 & 1421 & 1013 & 102 & 82 \\
\hline
\end{tabular}

Table 2: Shows the average number of cars per hour at the sampling sites. 
Citation: Philip M, Louis H, Magu TO, Fidelis TT, Maitera ON, et al. (2017) Evaluation of the Levels of Some Heavy Metal Contents of Street Dust in Some Parts of Yola Metropolis, Adamawa State, Nigeria. J Environ Anal Toxicol 7: 453. doi: 10.4172/2161-0525.1000453

Page 4 of 4

$(\mathrm{Pb}, \mathrm{Cd}, \mathrm{Fe}$ and $\mathrm{Zn})$, generally increases with heavy traffic density and other anthropogenic activities such as blacksmithing, indiscriminate waste disposal, burning refuse especially plastic materials, Agricultural activities, mechanic workshops as reported by Louis et al. The average values of metal concentration were found to be lower at the control site compared with other sites, but highest metal concentration were found at locations which experience heavy traffic and anthropogenic activities. The level of the heavy metals obtained all fall above the EPA'S health limit indicating that the study sites are polluted by these heavy metals $(\mathrm{Cd}, \mathrm{Pb}, \mathrm{Fe}$ and $\mathrm{Zn})$ under studies.

\section{References}

1. Nazir R, Khan M, Masab M, Rehman HU, Rauf NU, et al. (2015) Evaluation of heavy metals $(\mathrm{Ni}, \mathrm{Cu}, \mathrm{Cd}, \mathrm{Cr}, \mathrm{Pb}, \mathrm{Zn}, \mathrm{Fe})$ in the soil, water and plants and analysis of physico-chemical parameters of soil and water collected from Tanda Dam Kohat. J Pham Sci \& Res 7: 89-97.

2. Louis $H$, Manassah $H$, Barminas JT, Bisong AE, Fidelis TT, et al. (2015) Screening of Persistent Organic Pollutant from Various Surface Water in Yola-North Local Government Area of Adamawa State. International Journal of Scientific and Research Publications, p: 5.

3. NIOHH (National Institute for Occupational and Health Hazard) (1999) Pocke guide to chemical hazards. Washington DC, United Nations Department of Health and Human Services.

4. Agency of Toxic Substances and Disease Registry (ATSDR) (2008) Environmental Health and Medicine Education

5. Page AL, Chang AC, El-Amamy M (1987) Cadmium levels in soil and crops in the united states. Lead, mercury, cadmium and arsenic in the environment 8 : 119-146.

6. Adriano DC (2001) Trace elements in terrestrial environments: biogeochemistry, bioavailability and risks of metals. 2nd edn. Springer, New York, p: 867.

7. Alhassan AJ, Sule MS, Atiku MK, Wudil AM, Dangambo MA, et al. (2012) Correlation between heavy metal concentration in street dust and level of traffic in major roads of Kano metropolis, Nigeria. Nigerian Journal of Basic and Applied Science 20: 161-168.

8. Adekola FA, Dosumu OO (2001) heavy metal determination in household dust from Illorin city. Nigeria J Nigeria Society for Experimental Biology 3: 217-221.

9. Ubwa ST, Abah J, Ada CA, Alechenu E (2013) Levels of some heavy metals contamination of street dust in the industrial and high traffic density areas of Jos Metropolis. Journal of Biodiversity and Environmental Sciences 3: 13-21.

10. Karmacharya N, Shakya PR (2012) Heavy metals in bulk and particle size fractions from street dust of Kathmandu city as the possible basis for risk assessment. Scientific World 10: 84-88.

11. Attahiru U, Birnin-Yauri UA, Muhammad C (2015) Acacia Nitolica as Bioindicator of Copper and Cobalt Pollution Due to Vehicular Emission along the Main Entrance Road of Usmanu Danfodiyo University, Sokoto-Nigeria. In J Adv Res Chem Sci 2: 1-8.

12. Nriagu JO, Davidson $\mathrm{Cl}$ (1986) Toxic Metals in the Atmosphere. Wiley, New York, pp: 1-32.

13. Arslan H (2001) Heavy metals in street dust in Bursa, Turkey. J Trace Microprobe Tech 19: 439-445.

14. Jiries A, Hussein $H$, Halaseh $Z$ (2001) The quality of water and sediments of street runoff in Amman, Jordan. Hydrol Process, John Wiley \& Sons Ltd 15: 815-824. 